\title{
Development of Interactive Infographic Learning Multimedia on Study Methodology Study Course of Economic Education Program of Mulawarman University
}

\author{
Sudarman, Sugeng, Hairullah \\ Mulawarman University \\ sudarman@fkip.unmul.ac.id daremantep@gmail.com
}

\begin{abstract}
This study aims to develop an interactive multimedia infographic learning based on HTML5, as well as test its feasibility and quality. The method used in this research is research and development (R\&D) with the DDDE development method (Decide, Design, Development, Evaluation). This research was conducted at the Economic Education Study Program FKIP Mulawarman University. The results of this study indicate that: (1) Multimedia interactive infographic learning developed based on HTML5 is suitable for offline use. (2) Multimedia interactive interactive infographic learning in research methodology courses have been declared feasible by experts of research methods teaching materials with an average value of 4.10 , multimedia learning experts with an average value of 4.15 , and multimedia practitioners of learning with an average value of 4.66. (3) Multimedia interactive infographic learning in research methodology courses has been tested to have good quality in individual trials with an average value of 3.83, in small group trials with an average value of 4.23 , and in field trials with an average value of 4.22 .
\end{abstract}

Keywords: infographic, interactive multimedia, research methodology

\section{INTRODUCTION}

Information, communication, and technology (ICT) as the result of communication technology development are essential for society, especially in the sector of education, robotics, public administration, work field, businesses, and health (Gastelú et. al., 2015:139). With the support of ICT development, those sectors have become more effective and efficient, specifically for education. Besides increasing effectivity and efficiency, ICT can increase students' interest and motivation in Education.

Learning multimedia is one of the examples of ICT application that helps decreasing lecturer burden in the delivery of the materials. The utilization of learning multimedia is adjusted to the institute's facility and infrastructure where the lecture takes place. Advance use of multimedia, like smartphones, makes students get easier access to various information and get a better learning environment (Ahmadigol and Fazelian, 2015:55). 
multimedia. As proof, during the observation, developers found that students expect to find more innovation for the teaching and learning activities within the classrooms.

In the current learning environment, students are weary for continuously facing whiteboard and ink or monotonous PowerPoint presentation. They expect the lecturer to bring innovative learning multimedia that attract their interest and motivation, in order for them to stay focus on the presented materials. Learning multimedia should directly interact with the students. Therefore, there should be interesting designated learning multimedia development that is feasible and can directly interact with students. Interactive infographic learning multimedia can be the solution (Lankow, 2012:20).

Based on the result of the informal interview with one of the lecturers for the study methodology course at Mulawarman University, the developers found that their current facilities and infrastructures are projectors, Wi-Fi connections, students' gadgets, and laptops. Those facilities and infrastructures can support the interactive infographic learning multimedia developed since that multimedia requires $\mathrm{Wi}-\mathrm{Fi}$ connection to distribute the materials, lecturer's laptop to be the hub of learning connection, and students' gadgets to be the recipients.

A learning process needs a strategy to deliver the prepared materials. That strategy consists of the multimedia used by the lecturer, students' activities, and the teaching-learning structure. That strategy is the way to deliver the materials to students, which later get and also give respond to students' feedback. According to Degeng (1989:142), there are aspects that lecturer need to consider in creating that strategy, they are (a) The multimedia can be in the form of person, tools or objects; (b) Students interaction with the multimedia refers to the students' activities and the roles of the multimedia; (c) the teaching and learning structure refers to the learning process in a big group, small group, or individual learning.

The paradigm of knowledge has been shifted, from something owned by someone detached from other knowledge to a result of a construction which will continuously correspond with the new knowledge.

Assimilation and accommodation are the fundamental processes to build knowledge (Piaget and Pritchard, 2009:18). Assimilation is a process where we input new knowledge into the mental structure. The knowledge is increased when there is new information to build new knowledge. On the other hand, accommodation is a process to change the mental structure which contradicts the existing information. Once the contradiction solved, there will an equilibrium will occur. Equilibrium is defined as a stable construction, without conflict between new information and the existing knowledge (Pritchard, 2009:20).

Learning media is one of the supporting aspects of the successful learning process in the school since it helps the delivery process within the classrooms (Arda, Sahrul, Darsikin, 2015:1). Computers have become the farthest milestone of learning media because computers can directly interact with the students. Karen (2002:2) states that generally, multimedia refers to the use of multiple media to present information. The combination can include texts, graphics, animations, pictures, videos, and audios. Thus, multimedia is a combination of two or more media to present information. According to Mayer (2009:4), multimedia is defined as the presentation of materials in the form of words and pictures.

Furthermore, Mayer (2009:63) proposes three assumptions from the cognitive theory of learning multimedia. The first, every individual has double channels. This assumes that human has different channels to process visual and auditoria information. The second, those two channels have different limited capacity to receive information. When information is provided through traditional or advances multimedia, a human can only accommodate some information in the working memory at a time. The third, humans actively involved in processing the information to construct new knowledge with the existing experience. Alan (2009:35) mentions that learning process happens when someone actively processes, chooses, manages, and integrates information from both visual and auditoria channels. Thus, multimedia helps someone to process the information they have 
received and connect that information with the existing information in the long term memory.

Infographic refers to the visualization of data or ideas which aim to quickly communicate complex information to the audience (Smiciklas, 2012:3). In other words, interactive infographics aim to deliver information faster and easily understood by the audience through visualization or picturization of the complex materials to be simpler. There are several kinds of infographics, they are (a) static infographics, (b) animation information, and (c) interactive infographics (www.houseofinfografics.com).

Static infographic is defined as not moving pictures. This infographic is the former form of an infographic. All the production process of the infographic is always started with the static infographic which later developed into the other forms of infographics. However, that process requires a deep understanding of the materials, good choice of colors, fonts, pictures, and layout. All of those aspects should be interesting and systematic to create good infographics.

Animation infographic is the infographic presented in the form of motion graphics. This infographic has a different presentation than the other two infographics. It is presented in the form of moving pictures completed with audio. There are two kinds of audio used in this infographics, narrational and musical audio. Narrational audio is used for infographics is used to explain the pictures showed for the audience with better listening skills. Contrarily, musical audio functions to awaken the audience's emotion. The emotion is usually in the form of passion and fun environment, or other positive emotion based on the chosen music.

According to Smiciklas (in Alshehri and Ebaid, 2016:3) interactive infographic multimedia features are able to:

Give more visual emphasis on the essential information, so, the students can easily find that information.

Logically arrange the information in the right order, make the students' activities run smoothly in order for them to find the relation between each information.
The combination of symbols, pictures, graphics, colors, and texts help the students to have a better understanding of the materials than textbooks. In other words, interactive infographics can easily and naturally interact with students who have various learning styles.

Interactive infographics depend on the use of visual interactive activities and multimedia, to increase students' learning motivation. Thus, the learning activities will be more dynamic and realistic.

The visual image of the information helps the lecturer to simplify the materials and to relate the materials to students' daily life to create meaningful and useful learning.

Interactive infographics give chances for students to understand facts and concepts from what they see, later, they connect that information to their visual memory to easily process the information to develop new experiences.

Interactive infographics help to connect visually represented information, thus, it reaches the learning principle, especially the connection communication principle.

\section{METHODOLOGY}

The study method used in this study is research and development (R\&D). This method is used to create a particular product and test its effectivity (Sugiyono, 2009:407).

Research and development focus on the process. The study does not create a product, the development is the one creates the object being studied on, instead. The development is done through various activities to create the product expected to reach their goal. Before the goal is reached, the products need to be tested. From the result of the test, we will know whether or not the product has reached the designated goals.

The product development in this study was done by decided, design, development, and evaluation (DDDE) model. Those four steps should be done sequentially and thoroughly. The development procedure of this interactive infographics learning multimedia used DDDE 
development model from Karen S. Ivers, Ann E. Barron (2002:23) with these following steps:

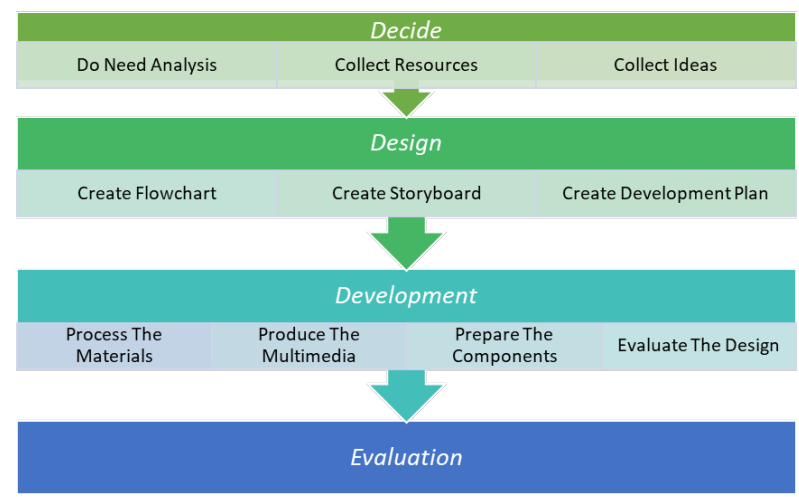

Picture 1. The Scheme of DDDE Development Model

\section{Decide}

The decision-making process requires several analysis as the consideration, they are doing need analysis, collecting resources and collecting ideas. In doing need analysis the researchers observed the place of study object (Economy Education Program of Mulawarman University). It started by interviewing students about the multimedia used in their learning process within the classrooms. Then, the researchers also conducted interviews with the study methodology courses lecturers about their understanding upon learning multimedia, the learning multimedia they usually use to deliver the materials, and the learning process in their classes. After that, the researchers looked for any information related to the facilities and infrastructures related to the learning multimedia provided by their university. The last, the researchers formulated the goals and feasible attainment they could find or students' could reach after the learning process. On the other hand, the resources collection process was done to gather all the tools needed to develop interactive infographics learning multimedia. For collecting ideas, the researchers discussed and brainstormed to create creative ideas in developing the multimedia, while associating the ideas with the result of analysis and the available tools they had collected before.

\section{Design}

This process involves: (a) Creating flowchart in order to collect all the materials for the product; (b) Creating storyboard in the written form that includes the planning, writing, and revising the storyboards and the display, effect, graphic, music, and others, which later validated; and, (c) Creating development planning, including the planning of narrative, visual effect, and music in the video.

\section{Development}

This process involves these steps: (a) Arranging the materials, this is to combine all the materials that have been collected earlier; (b) Creating multimedia in order to develop the display, effect, graphic, narrative, music, and the supportive instrument for the product development; (c) Preparing the other supportive components; and, (d) Evaluating and reviewing the design, in this steps the researchers needed help from a study methodology and learning multimedia experts to validate the product.

\section{Evaluation}

This is the final evaluation part of these development steps employed in this study. In this process, there were several tests to find students' opinions and the feasibility of the product.

Product testing was done to find out the product quality. The indicators to determine the product quality is the effectivity, efficiency, and attractiveness of the product. The testing was done in three steps, individual testing, small group testing, and field testing. The testing involved, (a) a subject for individual testing, (b0 four students for small group testing, and (c) 45 students for the field testing. To determine the participant for the testing the researchers took samples from several classes. 


\section{THE DATA}

\section{Data Analysis Technique}

In the validation process, the data analysis used was descriptive analysis. The data was collected by questionnaire, then calculated to find the average score. Based on Sukardjo (in Anjaya, 2013:72), the formula to get the average score of the product, which later also function as the conclusion, is:

\section{The Average Feasibility Score}

$$
=\frac{\text { Scores from each aspects }}{\text { Total number of questions in each aspects } \mathrm{x} \text { Total number of repondents }}
$$

The result of the calculation, then, was interpreted following the criteria in Table 1.

Table 1. Criteria of Product Feasibilities

\begin{tabular}{ll}
\hline Score & Qualitative Criteria \\
\hline $\bar{x}=5,00$ & Really Good \\
\hline $4,00 \leq \bar{x} \leq 4,99$ & Good \\
\hline $3,00 \leq \bar{x} \leq 3,99$ & Fairly Good \\
\hline $2,00 \leq \bar{x} \leq 2,99$ & Bad \\
\hline
\end{tabular}

The formula used to calculate the average score of product quality is:

Quality average $=($ score from the overall participants $) /($ numbers of questions $\times$ numbers of respondents )

Table 2. Product Quality Criteria

\begin{tabular}{ll}
\hline Score range & Qualitative Criteria \\
\hline $\bar{x}=5,00$ & Very Good \\
\hline $4,00 \leq \bar{x} \leq 4,99$ & Good \\
\hline $3,00 \leq \bar{x} \leq 3,99$ & Fair \\
\hline $2,00 \leq \bar{x} \leq 2,99$ & Poor \\
\hline $2,00<\bar{x}$ & Very Poor \\
\hline
\end{tabular}

\section{RESULTS AND DISCUSSIONS}

The results of this research cover four things based on the steps of research and development, Decide, Design, Development, and Evaluation. (a) Decide covers the analysis of needs, collection of sources needed, and collection of ideas needed in developing the media. (b) Design covers media flowchart, storyboard, and development framework. (c) The development covers the processes of developing multimedia based on the preparations in the previous steps, validation results from the expert of materials, and also the expert of learning multimedia. (d) The evaluation covers the results of try out in the form of students' responses as the learning multimedia users.

The Decide stage or the decision-making stage includes the result of need analysis, collection of sources needed, and collection of ideas needed in developing the media. The results of the need analysis are presented in Table 3 as follows.

Table 3. Results of Need Analysis (Learning Style)

\begin{tabular}{lccc}
\hline \multirow{2}{*}{ Measurement } & \multicolumn{3}{l}{ Learning Style } \\
\cline { 2 - 4 } & Visual & Auditory & Kinesthetic \\
\hline Total Point & 528 & 509 & 588 \\
\hline Average & 9,8 & 9,4 & 10,9 \\
\hline Percentage & $33 \%$ & $31 \%$ & $36 \%$ \\
\hline
\end{tabular}

Based on Table 3, it can be seen that students tend to implement the three learning styles in their learning with almost the same percentage. It implies that students will only use $33 \%$ of their skill to understand the course materials visually, $31 \%$ auditory, and $36 \%$ kinesthetically. It shows that it is necessary to give more effort into maximizing the three of their learning styles. It needs learning multimedia that possible to trigger the visual, auditory, and kinesthetic learning styles in the more maximum way.

The main sources obtained by the developer are the material that becomes the learning multimedia content since the learning multimedia design adjusts the learning content. The visual element was collected by downloading pictures that 
represent each sentence in the Research Methodology materials that have been prepared in the format of adobe illustrator (.ai) from a website www.freepik.com. The audio elements were collected by conducting a voice recording of each sentence in the materials using adobe audition software. The other audio elements were collected by downloading free background music provided at www.youtube.com. The process of collecting ideas was conducted at the same time with the process of collecting sources of materials.

The design process consists of flowchart media, storyboard, and planning the development. A flowchart is a construction framework of the multimedia that will be developed. The flowchart was developed based on the general framework of research methodology materials. All of the materials were presented in three parts of materials, they are video, description of materials, and animation. Those three parts become the multimedia to explain the materials for the users of infographic learning multimedia.

A storyboard is a visual that covers the steps of interactive infographic learning media usage. Those steps were developed based on the pages provided in the infographic learning multimedia by describing each element in the infographic learning multimedia pages. The elements described in this page were a menu on the main page, functions of icons in the video player, stop and play in the animation, icon to choose the animation, and others. Besides, in the step of making the development plan, the developer plan the duration of animation that will be developed in the next step by considering the visual elements with the prepared voice recording.

The Development process covers the process of developing multimedia based on the previous preparations, the result of validation from the expert of materials and expert of learning multimedia. Materials

Validation Results from the Expert of

The first step in the developing stage is compiling the materials. This step was successfully conducted by compiling all materials in the developed product. It is the compilation of all materials in the form of separated pictures that compiled in each explanation by using Adobe After Effect software as can be seen in Picture 1. The compiled pictures then were converted into a moving animation with various motions. Each motion will be adjusted with the voice recording that has been made before.

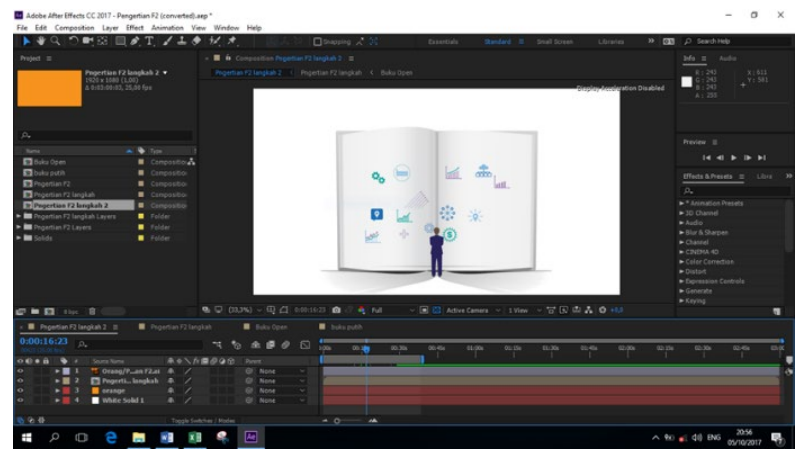

Picture 1. Process of Combining Pictures into an Animation

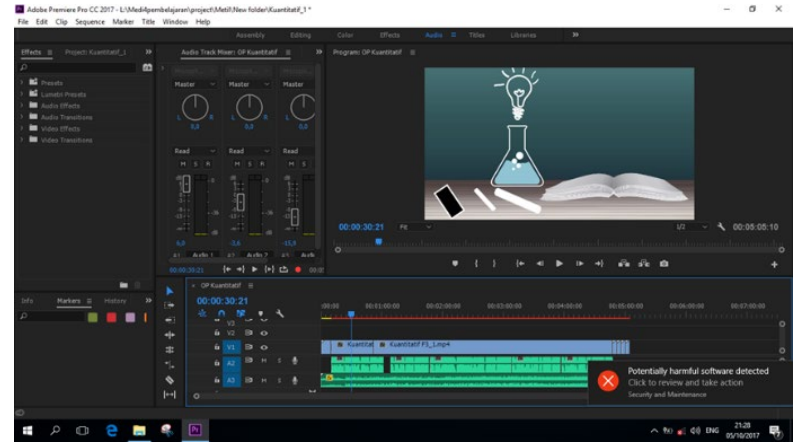

Picture 2. Process of Combining the Animation and Voice Recording

In the production step, the process was done using Adobe Premiere Pro software as can be seen in Picture 2. This software is used to combine the voice recording with the animation that the duration has been adjusted in the previous step and add the background music to make the delivering process of materials more relax.

In the designing process, the developer also equipped the product with a looped animation without any voices in a short duration. This additional animation was made to give some important and useful things that students need to know. The other additional component was the basis for infographic animation, HTML5 as the interactive infographics. HTML5 was developed using Adobe Muse and Adobe Animate Edge software. It is the important thing that allows interactive infographic learning multimedia can be 
used in hardware such as laptops, MacBook, Android, iPhone, or other cellular hardware. The complete description can be seen in Picture 4 as follow.

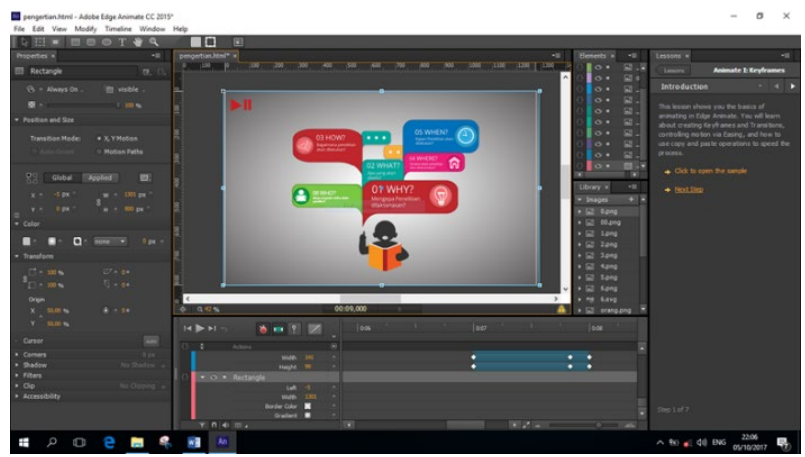

\section{Picture 4. Developing Web-Based Animation Using Adobe Edge Animate}

The evaluation of design was helped by two experts, the learning multimedia expert, the Research Methodology course expert, and also an education practitioner of learning multimedia.

The validator of materials experts was conducted by the lecturer of the FKIP Mathematics Study Program at Mulawarman University. This validation correlated with the effectivity, attractiveness, and the efficiency of materials. In terms of the materials effectivity, the validator measure how effective the materials presented in the interactive infographic multimedia based on the category of goal, content, technology, and design as the criterias. Results of the validation in materials effectivity show that the goal category has an average of 4.33. It indicates that the provided materials have already effective in achieving the goal of learning. The category of content gets an average of 4.50 and indicates that the materials have already effective to be presented in the learning process. The category of technology gets 4.33 which shows that the developed media support the presentation of the media. The messages design category gets 4.25 which indicates that the developed materials have an accepted message design. These results get the overall average of 4.36 which categorized as appropriate based on the effectivity criteria.
The second criteria are the attractiveness of the material. According to Normalita (2013:53), there is a relationship between the motivation of the study and the activity of the study. This condition shows that a learning activity can happen with learners' motivation to the learning materials so that the attractiveness of the materials becomes the criteria in the process of validation. The validation result by the expert of materials in terms of attractiveness shows that the materials' attractiveness in the goal category is in the average of 4.00 which indicates that the materials are relevant to students' learning motivation. The content category gets an average of 4.00 which shows that students are attracted to the content and learning materials provided. The category of technology gets an average of 4.40 which means that the presentation design of materials success to gain students' attraction to learn. In the category of messages design get an average of 4.20 which indicates that the messages of information provided in the materials are understandable. Thus, the average attractiveness criteria are 4.10 and show that the materials are attractively arranged and understandable.

The materials' efficiency validation was conducted to know how fast and easy for students to understand the materials. The expert validation by the expert of materials in terms of materials efficiency shows that the efficiency of materials in the goal category gets an average of 3.00 that shows that the materials are efficient. In the content category get an average of 4.00 which indicates that the content materials can be understood by students in a faster time. The technology category gets an average of 4.00 which means that the technology in the materials allows students to understand the materials faster. In the message design category get an average of 4.00 which shows that the information is well presented and able to enhance students' independence skill in understanding the materials. The overall average of efficiency is 3.83 so that the materials are efficient to be presented for students. 
The results of materials validation by the expert of materials can be seen in Table 4 as follow.

Table 4. Results of the Expert of Materials Validation

\begin{tabular}{llll}
\hline \multicolumn{3}{c}{ Average of Criteria } & $\begin{array}{c}\text { The } \\
\text { Overall } \\
\text { Average }\end{array}$ \\
\hline Effectiveness & Attractiveness & Efficiency & \\
\hline 4,36 & 4,10 & 3,83 & 4,10 \\
\hline $\mathbf{4 , 0 0} \leq \overline{\boldsymbol{x}} \leq \mathbf{4 , 9 9}$ & & Decent
\end{tabular}

Based on Table 4, the efficiency of the materials gets the lowest overall score compared to the effectiveness and attractiveness. According to the validator, there are some parts in the explanation of research methodology materials that discuss certain formulas that require additional learning multimedia such as whiteboard and marker. Regardless of that weakness, the overall average given by the validator is 4.10 which concludes that the multimedia is decent to be used.

\section{Results of Validation by Media Expert}

The validation of learning multimedia was conducted by doing a consultation and distributing a learning multimedia questionnaire to a teacher who masters the computer stuff. The questionnaire covers three criteria, they are effectiveness, attractiveness, and the efficiency of learning multimedia.

Validation of learning multimedia effectiveness was conducted to discover whether the learning multimedia usage is complete, accurate, and optimum. The validation was conducted twice since there were several problems in developing multimedia. The results of the effectiveness validation are presented as follows.

The effectiveness of multimedia in the goal category gets 4.00 in the first validation and 4.00 in the second validation. There was an improvement of the score in the second validation in the statement related to the compatibility of Xampp software users in sharing the wifi connection from a computer as the server of other users. The first validation was conducted by using a software that depends on an expensive additional tool to share the wifi connection to users while the computer has its potential to distribute the wifi connection through a special technique.

The first validation of the content category gets an average of 3.80. There were two problems in the first validations. It was related to audio and background. The first problem of audio was found that the recorded audio done by the developer can only be operated on the hardware with a stereo qualified speaker. There were several ways to operate the audio in hardware with mono audio technology such as android, iPhone, and windows phone. Finally, it was found out that the problem happens in the recording process. the developer used an active phantom with a stereo mode which makes hardware with mono technology was not able to produce an output. To solve this problem, the developer conducted a recording and decrease the voice quality and used mono mode in the recording process. The second problem was the background that was considered too plain. To solve this problem, the developer set an abstract picture as a multimedia background. The use of real pictures without any correlation toward the materials can disturb the concentration.

In the second validation, the expert on multimedia gave an average of 4.00. In the category of technology, the first validation gets an average of 4.00 or indicates that the technology used in learning multimedia is effective to be used. There was no comment upon the technology used in developing the learning multimedia. In the second validation, there was an improvement of the score into 4.57 since the developer revised the website to be a responsive page. The responsive display of the website page allows the display to be well operated on a laptop, android, iPhone, and windows phone. In the category of visual and messages design, there was no changing of the average score from the first to the second validation. The average score is 4.00 that indicates that the visual and message design is effective to be presented for students. The overall average of the effectiveness criteria has an improvement from 3.96 in the first validation to 4.22 in the second validation. It can be concluded that the interactive infographic learning multimedia is effective to be used. 


\section{The Attractiveness Criteria}

Learning multimedia holds a significant role in this era where the technology fastly advanced. The use of learning multimedia can attract students' attention to learning (Ismayani, 2012 page. 74). This is the measurement of learning multimedia attractiveness. The result of the first and second validation toward the attractiveness criteria on the category of goal gets 4.00 that indicates that the layout design able to attract students' attention to the learning process. In the category of content, the first and second validation get an average of 4.00. It indicates that the facilities, color, and music background in the interactive infographic learning multimedia are attractive to be used in the learning activities. In the category of technology, the average is 4.00 which means that the interactive infographic used in the offline website with animation video and interactive are attractive. In the category of visual and messages design, the average score is 4.00 which shows that the messages or information of materials presented in the form of audio and visual are attractive. There was no changing of the average score given by the validator in this criteria. The overall average in the attractiveness criteria got 4.00 in the first and second validation. It can be concluded that the interactive infographic learning multimedia is attractive for students.

\section{The Efficiency Criteria}

In this criteria, the validator assesses the level of ease and speed in using interactive infographic learning multimedia in the learning activities. The result of the validation learning multimedia on the efficiency criteria for the first validation category of goal and the second validation the second got an average score of 4.00 or it could be considered that interactive infographic multimedia is easy and fast in pursuing the goal of learning multimedia development. In the first content category validation got an average score of 4.00. In the second content category validation, the average score increased to 5.00 , the increase in the average score occurred because the navigation menu on the interactive infographic multimedia was redesigned to be simpler and easier to use. Average score on the second content category efficiency validation showed that facilities and navigation menu provided in the media is so easy to use and able to faster the learning process either inside classroom or individual learning process. The first and second technology category validation got an average score of 4.00 or it could be considered that interactive infographic learning multimedia could be used optimally using a computer / laptop and smart phone. Moreover, it can be used quickly and easily because it does not require special software to be installed. In the first and second message design categori got an average score of 4.00 or it could be categorized that the message or information on the material presented using the interactive infographic learning media is fast and easy to understand. The average score of efficiency criteria for all categories increased from the average score at the first validation of 4.00 to 4.22 at the second validation or it could be considered that interactive infographic learning multimedia is effective to use.

Based on Table 5. there is an increase in the average score, which is in the first multimedia validation that gets an average score of 4.00 and in the second multimedia validation it gets an average score of 4.15 or it can be concluded that interactive infographic learning multimedia is feasible to use.

\section{Table 5. First and Second Multimedia Expert Validation Results}

\begin{tabular}{lllll}
\hline \multirow{2}{*}{ Validation } & \multicolumn{2}{l}{ Average Score Each Criteria } & \multirow{2}{*}{$\begin{array}{l}\text { Overall } \\
\text { Average }\end{array}$} \\
\cline { 2 - 4 } & Effectivity & Attractiveness & Efficiency & \\
\hline First & 3,99 & 4,00 & 4,00 & 4,00 \\
\hline second & 4,22 & 4,00 & 4,22 & 4,15 \\
\hline $\mathbf{4 , 0 0} \leq \overline{\boldsymbol{x}} \leq \mathbf{4 , 9 9}$ & & & \\
\hline
\end{tabular}

\section{Validation of Learning Multimedia Practitioner}

The selected practitioner is a lecturer who is accustomed to using high-tech learning multimedia frequently. Multimedia Practitioner Validation is done using a questionnaire. The questionnaire for learning multimedia practitioners is the same as a questionnaire that is used for learning multimedia expert validators which has three criterion, which are effectiveness criteria, attractiveness criteria, and efficiency criteria. In every criterion has its four categories, namely the goal category, the content category, the technology category and the visual design and message design categories. 


\section{Effectiveness Criteria}

The effectiveness criteria as the first validation is done by learning multimedia practitioner. Learning multimedia practitioner will assess the effectiveness of learning multimedia in the categories of objectives, content, technology and visual and message design.

The result of the goal category validation gets an average score of 4.80 or it can be concluded that the software used is suitable with the objectives of developing infographic learning multimedia. The content category gets an average score of 4.60 or it can be concluded that the software used is accurate as an interactive infographic multimedia development tool in conveying information. The technology category gets an average score of 4.50 or it can be concluded that the software used is optimal as technical support in developing infographic learning multimedia. The visual design and message design category gets an average score of 4.43 or it can be concluded that the color selection, background, layout, and sound synchronization in the design of learning multimedia are accurate. While the effectiveness criteria gets an average score of 4.57 and it can be concluded that interactive infographic learning multimedia is effective to present learning material.

\section{Attractiveness Criteria}

The second criteria that is assessed by the learning multimedia practitioner validator is the attractiveness criterion. In this criterion the practitioner validates the level of attractiveness of layout design, video design, material description design and flash animation design. The results of the validation on the attractiveness criteria of the goal category gets an average score of 4.50 or it can be concluded that the layout design, video animation design, material description design and flash animation design are interesting to present learning material to the students. The content category gets an average score of 5.00 or it can be concluded that the facilities that are available, the colors selection and shapes of elements or icons, and the background are fascinating to present learning material to the students. The technology category gets an average score of 5.00 or it can be concluded that offline websites that are easily accessed, stable video performance, and flash animation are great as a media to present learning material to the students. The category of visual design and message design get an average score of 5.00 or it can be concluded that the learning material is very interesting when it is presented visual design and message design in infographic learning multimedia. The attractiveness criteria gets an average score of 4.85 and it can be concluded that the learning material is interesting when it is presented using infographic learning multimedia.

\section{Efficiency Criteria}

On efficiency criteria, learning multimedia practitioners validate the ease and speed of interactive multimedia infographic learning when it is used in class or when used independently. The results of the validation shows that the category gets an average score of 5.00 or it is concluded that interactive infographic learning multimedia is very easy and fast in achieving the goal of learning multimedia development. The content category gets an average score of 4.00 or it means that navigation facilities and content facilities (animated video and flash animation) are easy and fast to use. The technology category gets an average score of 5.00 or it means that interactive infographic learning multimedia can be used very optimally, easily and quickly without any special software installation process when it is used by students. The visual design and message design category gets an average score of 4.50 or it shows that the messages and information both visually and audio that are designed are easily understood when it is presented in class or used independently by the students. The efficiency criteria of multimedia interactive infographic learning gets an average score of 4.56 and it can be concluded that it is effective, start with the installation process to its use in class or independently by students.

Table 6. Validation Results of Multimedia Learning Practitioners

\begin{tabular}{llll}
\hline Average Score per Criteria & & $\begin{array}{l}\text { Overall } \\
\text { Average }\end{array}$ \\
\hline Effectiveness & Attractiveness & Efficiency & \\
\hline 4,57 & 4,85 & 4,56 & 4,66 \\
\hline $\mathbf{4 , 0 0} \leq \mathbf{x}^{-} \leq \mathbf{4 , 9 9}$ & Decent & \\
\hline
\end{tabular}


Based on Table 6. interactive infographic learning multimedia gets an average score of 4.66 and it is concluded that interactive infographic learning multimedia is feasible to be used as learning multimedia.

The results of learning multimedia validation from the material experts, multimedia instructors and multimedia practitioners in the form of interactive infographic learning multimedia are reviewed and improved according to the inputs provided by the validator team. The following is the product of improvement after validation by the validator including several multimedia pages, including opening page, Animation Information Page, Responsive Page, and others.

The opening page is designed simply by placing the menu button in the middle with a dark color so that it is easier to find. When it is clicked, a dialog box will appear containing all the pages listed in the interactive infographic learning multimedia and the user can choose to enter the desired page easily. For the detail it can be found in Figure 5, Figure 6, Figure 7, to Figure 10.

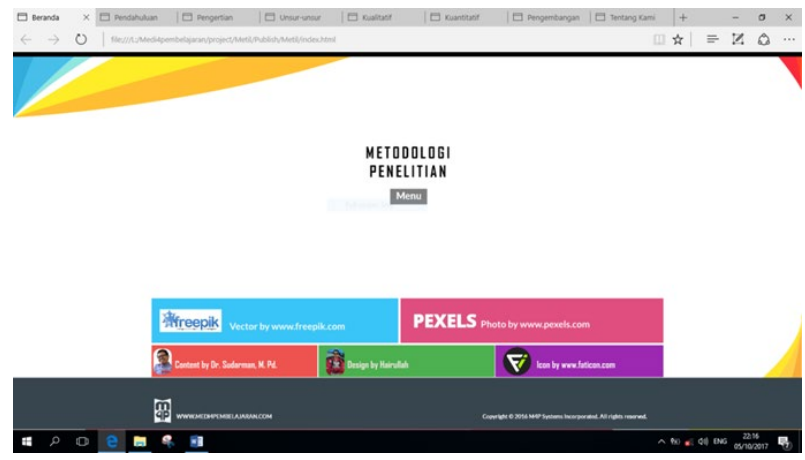

Picture 5. Learning Multimedia Opening Page

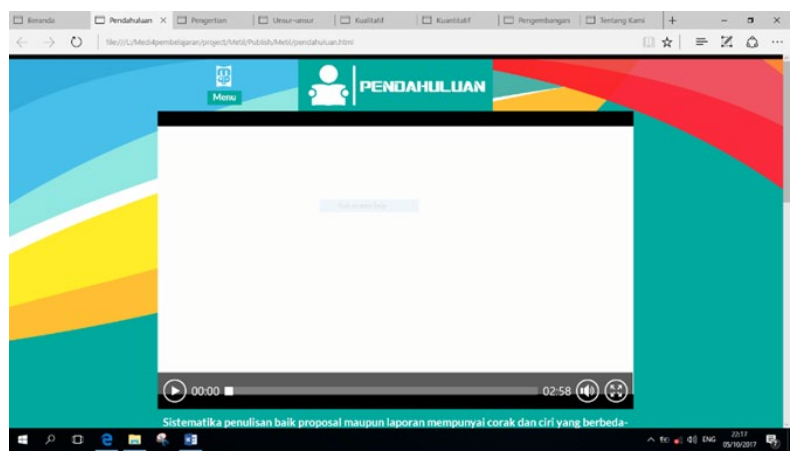

Picture 6. Animated Infographics (at the top) with Voice Video Format

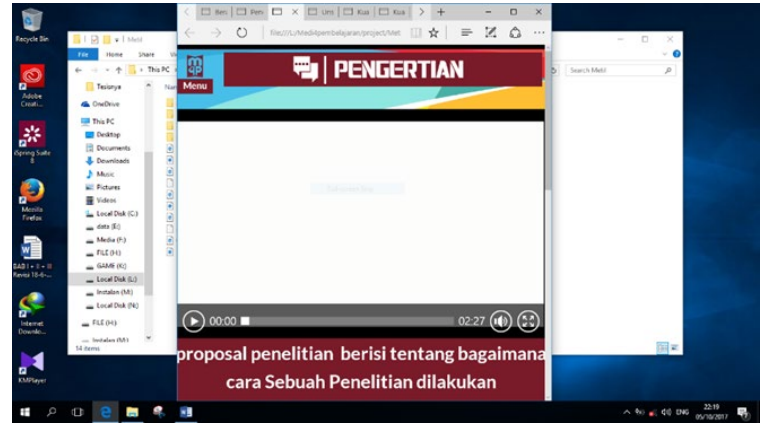

Picture 7. Responsive Pages and Openable on Cellular Devices

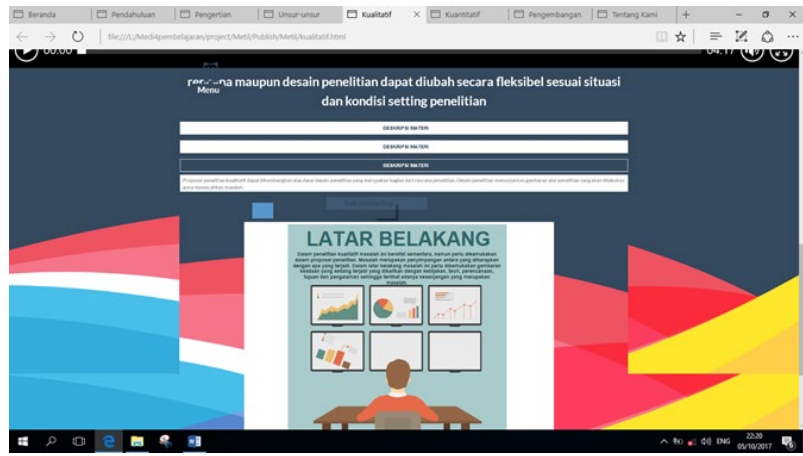

Picture 8. Material Description Page and Muted Animation in Every Pages on the below

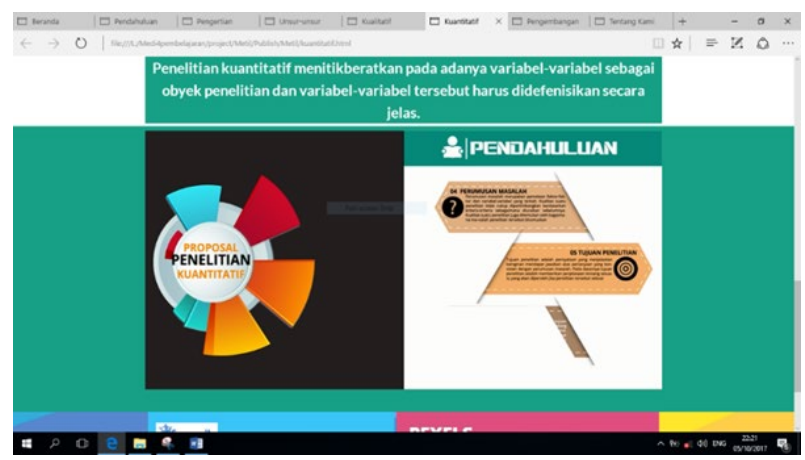

Picture 9. Important Sentence in Research Methodology Materials Page

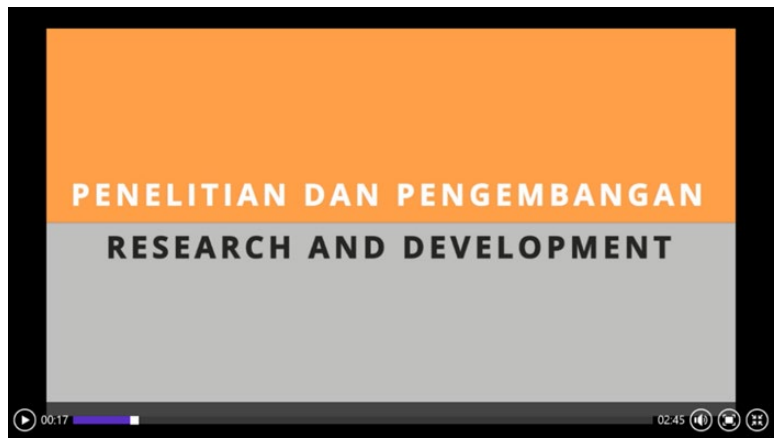

Picture 10. Videos to Watch or Display in Full Screen 
Pages on interactive infographic learning multimedia are designed flexibly, so that interactive infographic learning multimedia can be used in a variety of screen sizes, from the small Android resolution size $340 \times 640$ to the computer screen size 1920 X 1280.

Evaluation, at this stage, is carried out by direct testing of learning multimedia products to its users, students of the Economic Education Study Program at Mulawarman University. Product trials are carried out through three stages, namely individual trials, small groups trials, and field trials. The trial is conducted by asking the test subjects to use learning multimedia when doing the learning activities; then the test subjects are given a questionnaire to be filled with the aim of providing an assessment of the quality of the multimedia learning they have used.

Individual Trial. The first trial is conducted on one student who is randomly appointed to use multimedia learning; then the student is given a questionnaire to assess the learning multimedia. The assessment results show scores from numbers 1 to 5 , there are more scores of 3 with an average score of 3,6 . Score number 1 to 5 are an assessment score about the aspects of the program's display assessment. In this first trial, aspects of the display get a sufficient average score. This shows that students assess interactive infographic learning multimedia as having an unattractive display, so it needs to be improved on the display aspect. Improvements made are in the arrangement of infographic elements. In the aspect of expediency it gets an average score of "good". Even though students value quite enough on the aspects of appearance, students still consider that interactive infographic learning multimedia has beneficial aspects for them. So based on the score the results of the assessment from the first trial it gets an average value of 3.83 which is in the category of "quite good" quality.

Small Group Trial. The second trial is conducted on four students from the same class. They are randomly chosen to use multimedia learning when they were learning. Then the four students were given a questionnaire to assess the learning multimedia they use.
The results of the second trial produces better scores than before. In the aspect of the display get an average score of 4.40. There is an increase in the average score on the aspects of the display due to some improvement in the arrangement of elements in infographic learning multimedia, so that students assess that interactive infographic learning multimedia is interesting in their opinion. The aspect of benefits gets an average score of 4.11 , the average score is higher than the previous average score. The second trial participants consider that interactive infographic learning multimedia is beneficial for them when it is used during the learning activities in the research methodology course. The overall average value obtained from the second trial is 4.23 higher than the previous trial. The average value is included in the category of good quality.

Field Trial. The third try out is conducted to the students in the same class as the first and second trials. The trial is conducted with 45 participants as learning multimedia users. In this third trial, learning activities are carried out using interactive infographic learning multimedia. After the learning activities, all students are given an assessment questionnaire.

Field trial results show that the score of the trial results on the display aspect gets an average score of 4.14. In this third trial, the average score of aspects of the display has decreased once more, but the average score remains on the "good" quality criteria.

The same thing also happened in the aspect of benefit. In this aspect, it gets an average score of 4.32 , the average score is lower than the average score in the second trial. However, the score shows that interactive infographic learning multimedia has "good" quality in the aspect of benefit. The overall average score of this field trial is 4.22. Hence, from the results of the third trial, interactive infographic learning multimedia has a "good quality".

\section{CONCLUSION}

Several conclusions from this study are presented as follows:

a. Interactive infographic learning multimedia on research methodology courses is developed using the Decide, Design, Development and 
Evaluation (DDD-E) model by providing interactive animation video, interactive repetitive animations, and material descriptions that are attractively packaged in pages based on offline websites HTML5 which can be accessed through laptop, Android, Macbook, Iphone, Windows Phone and others.

b. Interactive infographic learning multimedia on educational research methodology courses has been categorized as:

1) feasible by experts in educational research methodology based on aspects of effectiveness, efficiency and attractiveness that achieve an average score that is appropriate to use;

2) feasible by learning multimedia experts based on aspects of effectiveness, efficiency and attractiveness that achieve an average score that is suitable to use;

3) feasible by multimedia learning practitioners based on aspects of effectiveness, efficiency and attractiveness that achieve an average score that is appropriate to use.

c. Interactive infographics learning multimedia on educational research methodology courses has been tested through a series of trials consisting of three stages as follows:

1) In individual trial, the quality is "quite good" based on the quality of the display aspect that gets the quality "quite good" and on the aspect of the benefit of getting "good" quality,

2) In small group trial the quality is "good" based on the quality of the aspect of the display that gets "good" quality and on the aspect of the benefit, it gets "good" quality.

3) In field trial the quality is "good" based on the quality of the aspect of appearance and the aspect of the benefit, it gets "good" quality.

\section{REFERENCES}

Ahmadigol, J. \& Pourandokht, F. (2015) The Effect Of Mobile Phones On Increasing Public Information: A Comparison Between The Student Of Kharazmi And Allameh Tabatabai University. International Journal Of Instructional Technology And Distance Learning 12(7), 55-63:. Iran.

Anjaya, T. (2013) Pengembangan Multimedia Pembelajaran Pneumatik dan Hidrolik Berbasis Adobe Flash Cs3 Professional Program Studi Diploma 3 Teknik Otomotif Universitas Negeri Yogyakarta. Universitas Negeri Yogyakarta.

Arda, Sahrul \& Darsikin. ((2015) Pengembangan Multimedia Pembelajaran Interaktif Berbasis Komputer Untuk Siswa SMP Kelas VIII. Pascasarjana Universitas Tadulako. Palu.

Aslan, A. (2015) PreService Teachers' Perceptions of ICT Integration in Teacher Education in Turkey. The Turkish Online Journal Of Educational Technology, 14(4). 97-110.

Degeng., INS. (1989) Teori Belajar I, Tasonomi Variabel. PPs Manajemen, Universitas Terbuka, Jakarta.

Ebaid, M. \& Alshehri, M. A. (2016) Effectiveness Of Using Interactive Infographic At Teaching Mathematics In Elementary School. European Centre For Research Training And Development. British Journal Of Education 4(3), $1-8$.

Gastelú, T. (2015) Student's Perception About Online Interaction, Access And Publishing Content For Academic Use. The Turkish Online Journal Of Educational Technology, 14(3), 138-144. Turkey.

Karen \& Baron, A. E. (2002) Multimedia Projects In Education: Designing, Producing, And Assesing (2nd Edition), Libraries Unlimited. USA.

Lankow, J. et al. (2012) Infographics: The Power Of Visual Storytelling. Canada: Column Five Media.

Mayer. R. E. (2009) Multimedia Learning (Prinsip Prinsip dan Alikasi), Pustaka Belajar: Yogyakarta. 
Normalita, A. (2013) Hubungan Antara Minat terhadap Prestasi Belajar Siswa Kelas VIII dalam Mata Pelajaran Seni Budaya di SMP Muham-madiyah 10 Yogyakarta. Jurusan Pendidikan Seni Musik Fakultas Bahasa dan Seni, Universitas Negeri Yogyakarta.

Pritchard, A. (2009) Ways Of Learning. Routledge: London.

Smaldino, Russell, Heinich, \& Molenda, et al. (2002) Instructional Technology and Multimedia for Learning Edisi 8. Pearson. Ohio.

Smiciklas, Mark. (2012) The Power of Infogra-phics. Que. Indiana.

Sugiyono. (2013) Cara Mudah Menyusun: Skripsi, Tesis, Disertasi. Al Fabeta: Bandung 